\title{
Social-Developmental Perspective on Intergroup Attitudes towards Immigrants and Refugees in Childhood and Adolescence: A Roadmap from Theory to Practice for an Inclusive Society
}

\author{
Seçil Gönültaş Kelly Lynn Mulvey \\ Department of Psychology, North Carolina State University, Raleigh, NC, USA
}

\author{
Keywords \\ Intergroup attitudes · Children · Youth · Immigrants and refugees · Promoting \\ intergroup relations
}

\begin{abstract}
The unprecedented rates of migration throughout the world have raised concerns about the social integration of immigrants and refugees due to possible experiences of prejudice, discrimination, and hostility from members of the host society. In this article, we review developmental and social theories and related research outlining children's and adolescents' intergroup attitudes towards immigrants and refugees. The discussion then moves to social agents that help shape children's and adolescents' attitudes regarding these relations. Theory-driven, empirically tested intervention studies that could potentially promote children's and adolescents' attitudes towards immigrants and refugees are discussed. We also address the limitations of current interventions, which were the starting points for this paper. Finally, we highlight important avenues for future research and make specific recommendations for practitioners and policy makers striving to promote harmonious intergroup relations across childhood and adolescence in social settings.

(c) 2019 S. Karger AG, Basel
\end{abstract}

Increasingly, individuals and families migrate to places where they hope to find security, jobs, and opportunities and often to escape threats of war, violence, political and civil instability, and poverty (World Migration Report, 2018). Although positive attitudes towards diversity are essential for an inclusive society in a globalized world, negative views toward immigrants and refugees are widespread throughout Europe, Asia, and America. While attitudes towards adult immigrants and refugees often dominate conversations and research on social integration, children comprise one-

\begin{tabular}{lcl}
\hline KARGER & & Seçil Gönültaş \\
E-Mail karger@karger.com & & North Carolina State University \\
www.karger.com/hde & Campus Box 7650, 711 Poe Hall \\
& Raleigh, NC 27695 (USA) \\
& E-Mail sgonult@ ncsu.edu
\end{tabular}


eighth of all international migrants in the world (31 million children out of 244 million total migrants; United Nations, 2016). Given the detrimental effects of prejudice and discrimination on immigrant and refugee children's mental health development, psychosocial adjustment and school adaptation, including manifestations of internalizing behaviors, such as depression, shyness, and social isolation, and externalizing behaviors, such as aggression, anger, and substance use (Sirin et al., 2015), it is critical that researchers and practitioners identify ways to foster positive intergroup relations among majority and migrant youth in order to provide a safe environment for all. This makes the understanding of children's and adolescents' attitudes toward immigrants and refugees an important developmental question.

In the following sections, we first review research demonstrating how children and adolescents develop intergroup attitudes towards immigrants and refugees. Considering the multifaceted nature of intergroup relations, we used the term "intergroup attitudes" to refer to thoughts, beliefs, evaluations, and behaviors concerning different social out-groups including immigrants and refugees (Levy \& Killen, 2008). Further, studies included in this review cover several subgroups of immigrants (documented immigrants, refugees, asylum seekers) as targets of prejudice since current theoretical perspectives do not address these groups separately and as studies have shown that all of these subgroups have experienced some level of discrimination and prejudice regardless of their immigrant status (Buchanan, Abu-Rayya, Kashima, Paxton, \& Sam, 2018). Starting with theories and empirical studies, which provide an understanding of intergroup attitudes towards immigrants and refugees in children, the discussion moves onto the social agents (e.g., parents and peers) that may shape children's and adolescents' attitudes. Further, we also address the limited research that examines the perspectives of immigrant and refugee children. Then we describe intervention studies aiming to reduce negative attitudes towards immigrants and refugees. Finally, we explore how these insights can benefit researchers and practitioners with a focus on implications for school-based practice and policy to reduce children's and adolescents' negative attitudes towards immigrants.

The literature on intergroup attitudes is becoming substantial but has yet to be reviewed in a systematic fashion by integrating social and developmental theories to critically evaluate how attitudes towards immigrants are understood during childhood and adolescence. As such, our paper approaches intergroup attitudes from a developmental perspective and bridges the ideas from different subfields of psychology. It, therefore, fosters an interdisciplinary dialogue that can inform a more comprehensive understanding of concepts such as identity, group membership, morality, and prejudice throughout development. This is a noble and significant mission for psychologists, since understanding the factors that can decrease or prevent negative outcomes of prejudice are considered to hold "paramount importance" (Rutland \& Killen, 2015) given the ubiquity of prejudice and social exclusion, especially in the current global climate. Taken together, this review aims to help bridge developmental and social theories by exploring the interplay between individual and social/contextual factors in understanding and shaping children's intergroup attitudes towards immigrants and refugees. Thus, we specifically examine different theoretical perspectives that attend to developmental trends in intergroup attitudes in order to provide a more nuanced understanding of intergroup relations, which is necessary for strengthening evidence-based interventions to promote positive intergroup attitudes across childhood and adolescence.

Attitudes towards Immigrants and Refugees in Children and Adolescents
Human Development 2019;63:90-111 DOI: $10.1159 / 000503173$ 


\section{Theoretical Frameworks for Understanding Intergroup Attitudes}

Children demonstrate evidence of intergroup attitudes towards many social groups by 3 and 4 years of age (for a review, see Raabe \& Beelmann, 2011). Evidence from a meta-analysis which examined developmental differences in intergroup attitudes during childhood demonstrated a peak in prejudice in early childhood (between the ages of 4 and 7 years) followed by a slight decrease in late childhood and early adolescence (Raabe \& Beelmann, 2011). Although there was no overall change in intergroup attitudes from early to late adolescence, the authors identify considerable developmental heterogeneity, indicating a possible role for the social context in shaping youth attitudes. Thus, while this meta-analysis documented interesting developmental differences, it also raised the issue of the importance of examining several moderators that may play a role in the development of prejudice including social factors and the interplay between individual and social-contextual factors. Therefore, in the current review, we examine a few key developmental and social theories that provide insight into the development of negative intergroup attitudes towards immigrants and refugees during childhood and adolescence with attention to such socialcontextual factors (peers, parents, etc.).

The Social Identity Development Theory (SIDT; Nesdale, 2004) proposes that children's attitudes, beliefs, and behaviors are significantly shaped by their social identity (e.g., race-ethnicity, nationality, gender, social class), which motivates them to pursue social contact with in-group members. SIDT, which is one of the most influential theories that bring aspects of cognitive development and social development together, identifies a four-phase developmental process that may lead to ethnic bias in multiethnic societies (Nesdale, 2004).

The first phase comprises the period prior to the age of 2, in which common markers of social identities (e.g., similarities in gender, ethnicity, etc.) do not have a great amount of influence on children. Nevertheless, as children are increasingly engaged in social interactions during this phase, it provides the foundations of social group relations. Social group awareness, the second phase, starts when children begin differentiating between others on the basis of signs of social identities. For example, children start to categorize themselves on the basis of their similarities or dissimilarities to others. In the social group preference phase, most of the children display in-group preferences based on identities including gender and ethnicity by school age. For example, as a consequence of ethnic self-identification, majority group children learn that they belong to a dominant ethnic group, which reflects a pivotal piece of children's identity jigsaw. The in-group preference phase is shaped around three themes. First, categorization leads children to interact with other children on the basis of similarity or dissimilarity. Thus, children are more inclined to behave differently towards in-group friends versus other children. Second, categorization leads to the out-group homogeneity effect (i.e., perceiving out-group members as being increasingly similar to each other). Lastly, the in-group preference phase involves concern for their group members as part of their in-group (Nesdale, 2017).

Moreover, SIDT argues that some children around the ages of 6-7 undergo the possible transition of in-group preference (i.e., favoring or choosing one group or individual over another based on ethnicity) to prejudice (i.e., negative attitudes or negative evaluative responses to groups as a whole or toward individuals due to their group membership). While children continue to have concern for their in-group, this 
transition also requires an emphasis on the characteristics of out-group members which might lead to out-group negativity. Further, the transition from in-group preference to out-group negativity depends on intergroup factors such as (a) whether children have prejudice towards out-group members, (b) whether in-group members believe that their in-group is threatened by out-group members, (c) the extent to which children perceive their out-groups as similar/dissimilar to their in-group, and (d) the extent to which children's in-group members perceive out-group negativity as a norm (Nesdale, 2017).

Research support for SIDT showed that preschool children's peer preferences might not be influenced by most of the social categories which are typically considered to be important by adults (Vaughn \& Santos, 2009). However, by the age of 5-6 years, most children can differentiate their own ethnic group and identify with it. Further, children have a tendency to protect their sense of social identity by excluding out-group members from their social in-group peer circle (Verkuyten \& Steenhuis, 2005). Similarly, they exclude in-group members who challenge or deviate from group norms and are inclined to leave a positive impression on their in-group members compared to out-groups (Rutland, Cameron, Milne, \& McGeorge, 2005). Consistent with SIDT, research also shows that children reveal a greater liking for their in-group over an out-group and even indicate greater liking for a lower status ingroup than for a higher status out-group (Nesdale, 2008). Moreover, the extant literature suggests that when children are highly identified with their in-group members or if they feel that the status of their in-group is threatened by out-group members, they are more likely to show prejudice and discrimination towards out-group members (Nesdale, 2008). Although in most of these studies, out-groups were created by a minimal group paradigm, this work still has important implications for understanding why children develop prejudice and discrimination towards immigrants and refugees - perceived as one of the most salient out-groups.

Similar to SIDT, Social Domain Theory (SDT; Nucci, 1981; Turiel, 1983) also offers a theoretical and empirical framework to understand the role of moral development in how children and adolescents reason about prejudice and discrimination towards different out-groups. From the SDT perspective, individuals consider distinct possible domains of social knowledge when making social evaluations: the moral domain (issues of welfare, justice, and rights), the social-conventional domain (societal expectations and conventions, group functioning, and social customs and norms), and the personal domain (one's choice over private matters and autonomy). Research based on SDT revealed that children and youth coordinate these domains during the decision-making processes in their social lives (Nucci, 2001). Similarly, when engaging in or challenging prejudicial behavior towards out-groups, including immigrant or refugee peers, children and adolescents can show complex forms of social reasoning. Children may attend to both the moral domain (what is fair or just) as well as the social-conventional domain (how can I stay loyal to my group) when reasoning about the treatment of others (Killen, Rutland, Abrams, Mulvey, \& Hitti, 2013). When these two types of reasoning come into conflict, children and adolescents, at times, choose between either giving priority to group concerns or to their own moral reasoning, or establishing a balance between their thoughts about group norms and group membership with their moral judgment regarding fairness and justice. This framework also notes that social-cognitive factors such as theory of mind can aid children in perceiving distinctions between domains, and that one's capacity

Attitudes towards Immigrants and Refugees in Children and Adolescents
Human Development 2019;63:90-111 DOI: $10.1159 / 000503173$ 
to perceive multiple and competing domains is key to developing social complex reasoning (Mulvey, Hitti, \& Killen, 2013).

By integrating elements from SIDT and SDT, the Social Reasoning Developmental perspective (SRD; Rutland, Killen \& Abrams, 2010) complements this line of research by looking at the influences of social factors such as group processes, group norms, group status and conflict context on attitudes towards out-groups. In line with SIDT, the SRD perspective argues that belonging to a particular social group is related to the expression of prejudice, and that relationships between social groups within any context are important in making certain social group memberships salient. Further, the SRD perspective examines the development of prejudice in the context of social-cognitive development and notes the interplay between morality and group identity through childhood and adolescence. This approach suggests that children's and adolescents' decision-making is influenced simultaneously by both morality principles and group processes, as these two processes are intertwined in development considering the early onset of both prejudice and morality.

Research drawing on this model has revealed how children and adolescents balance their concerns about group identity with their moral considerations and growing understanding of egalitarian principles (Killen et al., 2013). As an example, Hitti and Killen (2015) examined non-Arab American adolescents' views about inclusion and exclusion of non-Arab American and Arab American peers who shared interests within and between groups. They found that adolescents often chose to include peers with shared interests into their own cultural group, regardless of individual ethnicity. However, results also found that adolescents who had stereotypes and prejudice about Arab Americans were less likely to include an Arab American peer into their group than those who did not have stereotypes and prejudice. In a more recent study, Hitti et al. (2019) examined developmental patterns of Asian American children's and adolescents' attitudes and reasoning about cross-ethnic inclusion guided by the SRD framework. Findings showed that Asian American youth prioritized shared interests over ethnicity in their inclusivity decisions with age. In line with SRD, longitudinal changes from early to late adolescence showed that perspective-taking as an important social cognitive ability predicted changes in prejudice towards immigrant attitudes in Swedish majority adolescents. This was explained in terms of the possible role of social-cognitive processes in the development of intergroup attitudes (Miklikowska, 2018).

When we narrow our focus to intergroup attitudes towards immigrants and refugees, one other related and important context, although understudied, is threat perception as the Integrated Threat Theory proposed (Stephan, Ybarra, \& Bachman, 1999). Out-groups such as immigrants and refugees might pose both realistic threats (i.e., threats posed to in-group's power, material resources, and general welfare) and symbolic threats to in-group members (i.e., threats posed to an in-group's identity, values, norms, and way of living), which are associated with negative attitudes towards out-groups. For example, Vedder, Wenink, and van Geel (2017) studied intergroup relationships between Dutch majority students (ranging in age from 12 to 19 years) and their immigrant Muslim minority classmates in the Netherlands. They found that the pathway between contact and intergroup attitudes was mediated through the presence of threat perception and intergroup anxiety. This suggests that higher intergroup anxiety and perceived threat are related to higher negative intergroup attitudes and lower intergroup anxiety and that perceived threat is related to 
lower negative intergroup attitudes. Similarly, Nshom and Croucher (2017) found that Finnish adolescents (between 11 and 19 years of age) who perceive immigrants as posing realistic and symbolic threats are more likely to have prejudice towards immigrants, and this relationship is stable from early to late adolescence. They argued that adolescents perceived immigrants as a real threat due to social welfare issues (e.g., level of crime, availability of essential social services) and competition over scarce resources in health services, education, etc., and present data suggest that Finnish youth perceive immigrants as a symbolic threat because they evaluate them as dissimilar to their in-group in terms of cultural, national, and historical values. These findings are also in line with the studies drawing on an SRD framework which showed that in contexts when intergroup competition is salient, or resources are scarce, individuals sometimes justify ethnic-based intergroup exclusion (even in the form of subtle discrimination) due to the threat to the in-group identity (Rutland et al., 2010).

Taken together, research on children's and adolescents' anti-immigrant attitudes should focus on various factors and processes such as social-cognitive development, moral reasoning, in-group norms, group identification, cross-group friendship and feelings of threat.

\section{Out-Group Characteristics and Social Processes Shaping Children's and Adolescents' Cognition towards Immigrants and Refugees}

Drawing from these theoretical approaches, we review recent studies that investigate the role of characteristics of out-group and social processes underlying the development of intergroup attitudes towards immigrants and refugees through childhood and adolescence. Starting with how characteristics of the out-group members shape children's cognition about immigrants, a recent study (Gönültaş, Selcuk, Slaughter, Hunter \& Ruffman, 2019) shows how Turkish children's (aged between 9 and 13 years) mental state understanding, which is a possible contributor to relationships with out-group members, varies as a function of perceived similarity, prejudice, and threat perception towards out-groups (Syrian and Northern European targets), and social identification with the in-group (Turkish targets). Children were significantly less accurate when ascribing mental states to Syrian targets compared to Northern European targets. Findings also demonstrated that prejudice and perceived realistic threat significantly predicted lower mental state understanding for children in the Syrian target group. Similarly, children who had more discriminatory attitudes and realistic threat perception towards Syrian refugees were more likely to endorse normative beliefs (i.e., cognitive self-regulatory mechanisms which guide the assessment for what is appropriate or acceptable behavior) about aggression toward the refugees.

Another study conducted by Beißert, Gönültaş, and Mulvey (2019) provided evidence that children rely on contextual information about refugees' communication skills when evaluating social interactions with immigrants. German adolescents (aged 10-17) were asked to evaluate scenarios in which groups of youth were engaging in leisure time activities with peers in three conditions: German peers, Syrian refugees with good German language skills, and Syrian refugees with poor German language skills. Participants were less inclusive and also expected their peers to be less inclusive of the Syrian adolescents with poor German skills than of the Syrian targets

Attitudes towards Immigrants and Refugees in Children and Adolescents
Human Development 2019;63:90-111 DOI: $10.1159 / 000503173$ 
with good German skills and the German targets. Interestingly, however, there were no significant differences in rates of inclusion of the German protagonist and the Syrian refugee with good German skills. Thus, these results suggest that language skills are critical for the integration of out-group members, perhaps even over and above nationality or refugee status.

In a similar line, a recent study that investigates the role of personality in the perceived similarity between different groups showed that greater perceived similarity between Dutch children (aged 9-12 years) and refugee children was associated with more positive attitudes towards refugee children (Reches \& Feddes, 2019). Further, Dutch children were less likely to feel anxiety towards an extraverted refugee child compared to the introverted refugee child. This, in turn, leads to more positive attitudes towards refugee children.

Moreover, Brown, Ali, Stone, \& Jewell (2017) found that American children between the ages of 6 and 11 report more prejudice and fear towards Arab Muslim immigrants compared to other groups including Asian and Latino immigrants. The authors suggested that negative assumptions were invoked even with a rudimentary knowledge of the subject as only a small number of participants (only 29 of 136) were familiar with the term Muslim. Further, Brown et al. (2017) showed how children may absorb culturally biased attitudes via the media, even without a clear understanding of the specific targeted group as children's bias towards Arab Muslims was consistent with the common media portrayals of Arab Muslims immigrants, even though children reported little understanding of Arab Muslims. According to Brown et al. (2017), media might be one of the important tools which influences children's and adolescents' cognition about different out-groups including immigrants and refugees. Similarly, in one experimental study conducted in Australia, adolescents' (aged from 16 to 19) exposure to symbolic and economic threat advertisements led to a significant increase in negative attitudes towards immigrants (Schmuck \& Matthes, 2015). However, research about how media affect children's and adolescents' attitudes is scarce. Future research should consider the role of media sources on adolescents' and children's attitudes towards immigrants and refugees considering both the possibility of exposing anti-immigration sentiments in the media in everyday settings across Europe and the USA and the growing amount of media usage among children and adolescents (Arlt, Dalmus, \& Metag, 2019; Brown, 2011).

\section{Social Agents Shaping Children's and Adolescents' Attitudes towards Immigrants and Refugees}

The Ecological Model proposed by Bronfenbrenner (1979) conceptualizes the environment as a set of nested structures, each inside another, which emphasizes the importance of the bidirectional relationships between individuals' own characteristics, social agents, and context at the more macro level. The Ecological Model posits that those within one's social environment, such as parents and other individuals with whom one has a close relationship, influence children's thinking about whom they should dislike and towards whom they should show prejudicial and discriminatory attitudes. We review some of the recent studies examining the social agents shaping children's and adolescents' attitudes towards immigrants and refugees (Table 1). 
Table 1. Summary of studies investigating social agents shaping children's and adolescents' intergroup attitudes towards immigrants and refugees

\begin{tabular}{|c|c|c|c|c|c|}
\hline Reference & Social agents & Study sample & Study design & Study variables & Summary \\
\hline $\begin{array}{l}\text { Gniewosz and } \\
\text { Noack, } 2015\end{array}$ & Parents & $\begin{array}{l}1,289 \text { adolescents } \\
\text { (aged } 12-16 \text { years) } \\
\text { and their parents } \\
\text { Germany }\end{array}$ & $\begin{array}{l}\text { Longitudinal with } \\
\text { five time points } \\
\text { (cohort-sequen- } \\
\text { tial) }\end{array}$ & $\begin{array}{l}\text { Immigrants (general); } \\
\text { self-report } \\
\text { DV: adolescents' and their } \\
\text { parents' intolerant atti- } \\
\text { tudes toward immigrants }\end{array}$ & $\begin{array}{l}\text { Changes in the adoles- } \\
\text { cents' attitudes were } \\
\text { predicted by parents' } \\
\text { attitudes across time } \rightarrow \\
\text { major effect in early } \\
\text { adolescence (between } \\
\text { grade } 6 \text { and } 7 \text { ) } \\
\text { These effects last until } \\
\text { the age of } 16\end{array}$ \\
\hline $\begin{array}{l}\text { Miklikowska, } \\
2016\end{array}$ & Parents & $\begin{array}{l}507 \text { adolescents } \\
\left(M_{\text {age }}=13.41\right) \text { and } \\
\text { their parents } \\
\text { Sweden }\end{array}$ & $\begin{array}{l}\text { Longitudinal } \\
\text { design with } \\
\text { two time points }\end{array}$ & $\begin{array}{l}\text { Immigrants (general); } \\
\text { self-report } \\
\text { DV: prejudice and toler- } \\
\text { ance towards immigrants } \\
\text { Other study variables: } \\
\text { adolescents' perceptions of } \\
\text { perceived parental support }\end{array}$ & $\begin{array}{l}\text { Bidirectional influences } \\
\text { between parents and } \\
\text { adolescents' attitudes } \\
\text { Youth who perceived } \\
\text { their parents as support- } \\
\text { ive } \\
\text { showed higher corre- } \\
\text { spondence in prejudice } \\
\text { than youth with low } \\
\text { parental support }\end{array}$ \\
\hline
\end{tabular}

\begin{tabular}{|c|c|c|c|c|}
\hline $\begin{array}{l}\text { Smith, Maas, } \\
\text { and van } \\
\text { Tubergen, } 2015\end{array}$ & Parents & $\begin{array}{l}5,683 \text { native and } \\
3,371 \text { immigrant } \\
\text { adolescents }(+15 \\
\text { years old) and their } \\
\text { parents } \\
\text { Germany and the } \\
\text { Netherlands }\end{array}$ & $\begin{array}{l}\text { Cross-sectional } \\
\text { design }\end{array}$ & $\begin{array}{l}\text { Immigrants; self-report } \\
\text { DV: out-group attitudes } \\
\text { Other study variables: } \\
\text { number of out-group class } \\
\text { peers, SES, the importance } \\
\text { of in-group traditions to } \\
\text { parents, parental out- } \\
\text { group friends }\end{array}$ \\
\hline
\end{tabular}

More parental out-group

friends and less impor-

tance placed on main-

taining in-group tradi-

tions is related to chil-

dren's number of out-

group friends;

this relationship is

mediated by children's

out-group attitudes

\begin{tabular}{|c|c|c|c|c|c|}
\hline $\begin{array}{l}\text { Meeusen and } \\
\text { Dhont, } 2015\end{array}$ & Parents & $\begin{array}{l}1,530 \text { adolescents } \\
\text { (aged } 14-19 \text { years) } \\
\text { and their parents } \\
\text { Belgium }\end{array}$ & $\begin{array}{l}\text { Only one wave of } \\
\text { a longitudinal } \\
\text { study }\end{array}$ & $\begin{array}{l}\text { Immigrants and other } \\
\text { groups; self-report } \\
\text { DV: attitudes towards four } \\
\text { different target groups } \\
\text { including immigrants } \\
\text { Other study variables: } \\
\text { political discussion with } \\
\text { parents, parental educa- } \\
\text { tion, and political interest } \\
\text { of the child }\end{array}$ & $\begin{array}{l}\text { The parent-child similar- } \\
\text { ity was significant for all } \\
\text { the prejudice compo- } \\
\text { nents; adolescents who } \\
\text { discuss social and } \\
\text { political issues with their } \\
\text { parents were more likely } \\
\text { to be similar to their } \\
\text { parents in prejudice and } \\
\text { levels of authoritarianism }\end{array}$ \\
\hline $\begin{array}{l}\text { Munniksma, } \\
\text { Flache, } \\
\text { Verkuyten, } \\
\text { and Veenstra, } \\
2012\end{array}$ & Parents & $\begin{array}{l}150 \text { parents who have } \\
\text { 6th-grade middle } \\
\text { school, students } \\
\text { The Netherlands }\end{array}$ & $\begin{array}{l}\text { Cross-sectional } \\
\text { design }\end{array}$ & $\begin{array}{l}\text { Immigrants (general); } \\
\text { self-report } \\
\text { DV: parental acceptance of } \\
\text { children's out-group } \\
\text { relations } \\
\text { Other study variables: } \\
\text { family reputation vulner- } \\
\text { ability, the religiosity of } \\
\text { parents, background } \\
\text { variables (education, } \\
\text { ethnicity) }\end{array}$ & $\begin{array}{l}\text { Concerns about culture } \\
\text { transmission and family } \\
\text { reputation are related to } \\
\text { parental acceptance of } \\
\text { out-group contact; } \\
\text { status considerations } \\
\text { explain differences in } \\
\text { parental acceptance of } \\
\text { their children's close } \\
\text { contacts with different } \\
\text { out-groups }\end{array}$ \\
\hline $\begin{array}{l}\text { Miklikowska, } \\
2017\end{array}$ & $\begin{array}{l}\text { Parents and } \\
\text { peers }\end{array}$ & $\begin{array}{l}517 \text { adolescents } \\
\left(M_{\text {age }}=13.41 \text { at } \mathrm{T} 1\right) \\
\text { and their parents } \\
\text { Sweden }\end{array}$ & $\begin{array}{l}\text { Longitudinal } \\
\text { design with } \\
\text { three time points }\end{array}$ & $\begin{array}{l}\text { Immigrants (general); } \\
\text { self-report and peer } \\
\text { nominations } \\
\text { DV: parents' and peers' } \\
\text { anti-immigrant attitudes } \\
\text { Other study variables: } \\
\text { intergroup friendships, } \\
\text { empathy, and socioeco- } \\
\text { nomic background }\end{array}$ & $\begin{array}{l}\text { Significant effects of } \\
\text { parents, peers, inter- } \\
\text { group friendships, and } \\
\text { socioeconomic back- } \\
\text { ground on changes in } \\
\text { youth attitudes; } \\
\text { adolescents with immi- } \\
\text { grant friends were less } \\
\text { affected by parents' and } \\
\text { peers' prejudice than } \\
\text { youth without immigrant } \\
\text { friends }\end{array}$ \\
\hline
\end{tabular}

Attitudes towards Immigrants and Refugees in

Human Development 2019;63:90-111 
Table 1 (continued)

\begin{tabular}{|c|c|c|c|c|c|}
\hline Reference & Social agents & Study sample & Study design & Study variables & Summary \\
\hline $\begin{array}{l}\text { Eckstein, Šerek, } \\
\text { and Noack, } \\
2018\end{array}$ & Siblings & $\begin{array}{l}362 \text { adolescent } \\
\text { sibling dyads; (older } \\
\text { siblings: } M_{\text {age }}=17.77 \text {, } \\
\text { younger siblings: } \\
M_{\text {age }}=13.61 \text { ) } \\
\text { Germany }\end{array}$ & $\begin{array}{l}\text { Longitudinal } \\
\text { design with } \\
\text { two time points }\end{array}$ & $\begin{array}{l}\text { Immigrants (general); } \\
\text { self-report } \\
\text { DV: intolerance for } \\
\text { immigrants } \\
\text { Other study variables: } \\
\text { social dominance orienta- } \\
\text { tion, family relationship } \\
\text { quality, SES }\end{array}$ & $\begin{array}{l}\text { Older siblings' inter- } \\
\text { group attitudes predicted } \\
\text { younger siblings' atti- } \\
\text { tudes } \rightarrow \text { the effect was } \\
\text { moderated by gender; } \\
\text { a significant moderation } \\
\text { by age indicated that } \\
\text { younger siblings affected } \\
\text { older siblings' social } \\
\text { dominance orientation } \\
\text { with increasing age }\end{array}$ \\
\hline $\begin{array}{l}\text { Hjerm, Eger, } \\
\text { and Danell, } \\
2018\end{array}$ & Peers & $\begin{array}{l}1,009 \text { adolescents } \\
\text { (aged } 13-16 \text { years at } \\
\text { T1) } \\
\text { Sweden }\end{array}$ & $\begin{array}{l}\text { Longitudinal } \\
\text { design with } \\
\text { five time points }\end{array}$ & $\begin{array}{l}\text { Immigrants (general); } \\
\text { self-report, peer nomina- } \\
\text { tions, and social network } \\
\text { DV: multidimensional } \\
\text { index of anti-immigrant } \\
\text { sentiment } \\
\text { Other study variables: the } \\
\text { level of prejudice in one's } \\
\text { network, popularity/ } \\
\text { prestige of students }\end{array}$ & $\begin{array}{l}\text { Adolescents in low-prej- } \\
\text { udice networks become } \\
\text { less prejudiced over time } \\
\text { while adolescents in } \\
\text { high-prejudice networks } \\
\text { become more prejudiced } \\
\text { over time; adolescents' } \\
\text { own positions in their } \\
\text { networks matter: net- } \\
\text { work centrality is in- } \\
\text { versely related to preju- } \\
\text { dice }\end{array}$ \\
\hline $\begin{array}{l}\text { Van Zalk and } \\
\text { Kerr, } 2014\end{array}$ & Peers & $\begin{array}{l}1,542 \text { adolescents } \\
\left(M_{\text {age }}=15.31 \text { at } \mathrm{T} 1,\right. \\
\text { high school students) } \\
\text { Sweden }\end{array}$ & $\begin{array}{l}\text { Longitudinal } \\
\text { design with } \\
\text { three time points }\end{array}$ & $\begin{array}{l}\text { Immigrants (general); } \\
\text { self-report and peer } \\
\text { nominations } \\
\text { DV: tolerance and preju- } \\
\text { dice toward immigrants } \\
\text { Other study variables: } \\
\text { intergroup friendships, } \\
\text { callous-unemotional traits }\end{array}$ & $\begin{array}{l}\text { Intergroup friendships } \\
\text { predicted stronger } \\
\text { increases in tolerance, } \\
\text { which, in turn, predicted } \\
\text { decreases in prejudice } \\
\text { toward immigrants; } \\
\text { tolerance and prejudice } \\
\text { toward immigrants were } \\
\text { differentially influenced } \\
\text { by social experiences and } \\
\text { problematic personality } \\
\text { traits }\end{array}$ \\
\hline $\begin{array}{l}\text { De Tezanos- } \\
\text { Pinto, Bratt, } \\
\text { and Brown, } \\
2010\end{array}$ & Peers & $\begin{array}{l}823 \text { adolescents } \\
\text { (aged } 13-15 \text { years) } \\
\text { Norway }\end{array}$ & $\begin{array}{l}\text { Cross-sectional } \\
\text { design }\end{array}$ & $\begin{array}{l}\text { Immigrants (Turkish and } \\
\text { Pakistani, Indian); self- } \\
\text { report } \\
\text { DV: attitudes towards } \\
\text { immigrants } \\
\text { Other study variables: peer } \\
\text { norms against contact, } \\
\text { intergroup anxiety, indi- } \\
\text { rect cross-group friend- } \\
\text { ship, direct cross-group } \\
\text { friendship }\end{array}$ & $\begin{array}{l}\text { In-group friends affect } \\
\text { attitudes towards the } \\
\text { out-group by changing } \\
\text { the perception of in- } \\
\text { group norms and by } \\
\text { reducing intergroup } \\
\text { anxiety; direct contact } \\
\text { improved attitudes only } \\
\text { by reducing intergroup } \\
\text { anxiety and did not affect } \\
\text { the perception of in- } \\
\text { group norms }\end{array}$ \\
\hline $\begin{array}{l}\text { Hjerm, Sevä, } \\
\text { and Werner, } \\
2018\end{array}$ & $\begin{array}{l}\text { Teachers/ } \\
\text { school } \\
\text { curriculum }\end{array}$ & $\begin{array}{l}4,675 \text { adolescents } \\
\text { (aged } 16-18 \text { years) } \\
\text { Sweden }\end{array}$ & $\begin{array}{l}\text { Cross-sectional } \\
\text { design }\end{array}$ & $\begin{array}{l}\text { Immigrants (general); } \\
\text { self-report } \\
\text { DV: anti-immigrant } \\
\text { attitudes } \\
\text { Other study variables: } \\
\text { critical thinking, multicul- } \\
\text { tural education, qualifica- } \\
\text { tions of teachers, parents' } \\
\text { education and school type }\end{array}$ & $\begin{array}{l}\text { Higher exposure to } \\
\text { teaching about critical } \\
\text { thinking as well as } \\
\text { multiculturalism is } \\
\text { related to lower levels of } \\
\text { anti-immigrant attitudes; } \\
\text { students in schools with } \\
\text { a high proportion of } \\
\text { certified teachers were } \\
\text { more likely to have lower } \\
\text { levels of anti-immigrant } \\
\text { attitudes }\end{array}$ \\
\hline
\end{tabular}


Table 1 (continued)

\begin{tabular}{|c|c|c|c|c|c|}
\hline Reference & Social agents & Study sample & Study design & Study variables & Summary \\
\hline $\begin{array}{l}\text { Geerlings, Thijs, } \\
\text { and Verkuyten, } \\
2017\end{array}$ & Teachers & $\begin{array}{l}389 \text { adolescents (aged } \\
8-13 \text { years; study } 1) ; \\
384 \text { adolescents (aged } \\
9-13 \text { years; study } 2) ; \\
363 \text { adolescents (aged } \\
\text { 8-12 years; study } 3 \text { ) } \\
\text { The Netherlands }\end{array}$ & $\begin{array}{l}3 \text { cross-sectional } \\
\text { designs }\end{array}$ & $\begin{array}{l}\text { Immigrants (Turkish- and } \\
\text { on the other Moroccan } \\
\text { people); self-report } \\
\text { DV: out-group attitudes } \\
\text { towards different groups } \\
\text { Other study variables: the } \\
\text { quality of the student- } \\
\text { teacher relationship, } \\
\text { perceived multicultural } \\
\text { teacher norm, ethnic } \\
\text { identification, intergroup } \\
\text { anxiety, motivation for } \\
\text { intercultural openness }\end{array}$ & $\begin{array}{l}\text { Student-teacher relation- } \\
\text { ships were related to } \\
\text { students' positive out- } \\
\text { group attitudes; the } \\
\text { quality of the student- } \\
\text { teacher relationship itself } \\
\text { is relevant for children's } \\
\text { ethnic out-group atti- } \\
\text { tudes and not moderated } \\
\text { by the perceived teacher } \\
\text { norm on multicultural- } \\
\text { ism }\end{array}$ \\
\hline $\begin{array}{l}\text { Miklikowska, } \\
\text { Thijs, and } \\
\text { Hjerm, } 2019\end{array}$ & Teachers & $\begin{array}{l}671 \text { adolescents (aged } \\
13-14 \text { years at T1) } \\
\text { Sweden }\end{array}$ & $\begin{array}{l}\text { Longitudinal } \\
\text { design with five } \\
\text { time points }\end{array}$ & $\begin{array}{l}\text { Immigrants (general); } \\
\text { self-report } \\
\text { DV: anti-immigrant } \\
\text { attitudes } \\
\text { Other study variables: } \\
\text { perceived teacher support, } \\
\text { social trust, perceived } \\
\text { family finances, classroom } \\
\text { diversity }\end{array}$ & $\begin{array}{l}\text { Perceived teacher sup- } \\
\text { port was associated with } \\
\text { lower prejudice } \rightarrow \\
\text { fluctuations in teacher } \\
\text { support were related to } \\
\text { fluctuations in youth } \\
\text { prejudice; classrooms } \\
\text { where students shared } \\
\text { the experience of teacher } \\
\text { support were lower in } \\
\text { prejudice than class- } \\
\text { rooms with weaker } \\
\text { teacher support }\end{array}$ \\
\hline
\end{tabular}

DV, dependent variable; $M_{\text {age }}$, mean age; SES, socioeconomic status; T1, time 1 .

Starting with the role of parents in the development of intergroup attitudes as primary socializing agents, studies showed substantial correlations between adolescent and parental ratings on ethnic prejudice, race- and ethnicity-related attitudes as well as immigration-related attitudes. More specifically, children learn prejudice from their parents, mimic their prejudicial attitudes and behaviors in their attempts to conform to their environment and to please these authority figures or caregivers. Similarly, parents who increase the salience of social groups in their evaluations feed their children's development of stereotypical and prejudicial attitudes (see Degner \& Dalege, 2013, for a meta-analysis).

In the context of attitudes towards immigrants and refugees, research documenting the important role of parents in shaping their children's attitudes has emerged from both longitudinal and cross-sectional studies. Studies showed that parents' own intergroup attitudes, their intergroup contact with immigrants and their given importance to in-group traditions predict their children's attitudes towards immigrants (e.g., Munniksma, Flache, Verkuyten, \& Veenstra, 2012; Smith, Maas, \& van Tubergen, 2015). Further, adolescents (aged between 14 and 19 years) whose parents are more open to discuss social and political issues with their children were more likely to be similar to their parents in different prejudicial domains including in attitudes towards immigrants (Meeusen \& Dhont, 2015).

The power of parents' influence, however, is susceptible to change across different developmental periods. For example, a longitudinal study conducted with German

Attitudes towards Immigrants and Refugees in Children and Adolescents
Human Development 2019;63:90-111 DOI: $10.1159 / 000503173$ 
adolescents between the ages of 12 and 16 revealed that adolescents' attitudes towards immigrants are influenced by parents primarily during early adolescence and that parental influences on their children's attitudes decreased over time through late adolescence (Gniewosz \& Noack, 2015). All the studies summarized above provide evidence for the unidirectional parent-to-child transmission of attitudes. However, Miklikows$\mathrm{ka}$ (2016) showed that there are reciprocal relations between parents' and adolescents' (mean age $=13.41$ years) intergroup attitudes towards immigrants (prejudice and tolerance). Further, results showed that the extent of parents' immigrant attitudes predicted a change in youth attitudes depending on the perceived parental support, indicating that the quality of the relationship between parents and adolescents moderated the strength of intergenerational transmission of both prejudice and tolerance. As a part of the family, older siblings (aged between 13 and 26 years) were also found to influence their younger siblings' (aged between 12 and 17 years) intolerant attitudes towards immigrants. More specifically, older siblings' attitudes were the only significant predictors for their younger siblings' attitudes even controlling for parental influence on their children's intergroup attitudes (Eckstein, Šerek, \& Noack, 2018).

In line with the Ecological Model, other social agents and social factors, such as peers, teachers, the classroom environment and the media, have been proposed to be involved in shaping children's and adolescents' attitudes towards immigrants and refugees. Negative peer norms (i.e., children's and adolescents' perceptions about the frequency and approval of prejudice and discrimination in the peer group) have been found to be one of the key barriers to cross-group friendship development (Aboud \& Sankar, 2007). Similarly, peer group norms that condone exclusion influence children's inclusivity towards ethnic out-group members (Hitti \& Killen, 2015; Nesdale, 2008). Thus, peer norms have the potential to create an environment in which positive relations with immigrants can develop. For example, a study conducted with Norwegian school students (aged between 13 and 15 years) found that students whose peers held more positive norms for out-groups held also more positive out-group attitudes toward immigrants (De Tezanos-Pinto, Bratt, \& Brown, 2010). Cross-group friendship also indirectly reduced prejudice by supporting positive attitudes in Swedish adolescents. This indicates that nonimmigrant adolescents who develop friendships with immigrants might improve their knowledge about immigrants and increase empathic concern (Van Zalk \& Kerr, 2014).

Similarly, adolescents (aged 16-18 years) who are in low-prejudice peer networks become less prejudiced over time while adolescents in high-prejudice networks become more prejudiced over time (Hjerm, Eger, \& Danell, 2018). Along similar lines, Miklikowska (2017) investigated the effects of peers' and parents' anti-immigrant attitudes as well as cross-group friendships on relative changes in adolescents' attitudes toward immigrants. Results suggest that youth with more prejudiced parents and peers, as well as no intergroup friends, increased in prejudice compared to youth with less prejudiced parents, peers, and intergroup friends. Moreover, the findings also demonstrated that youth with immigrant friends were less likely to be influenced by peers and parents' attitudes compared to those who do not have immigrant friends in early adolescence, indicating longitudinal evidence for the moderating effects of intergroup friendships. Although possible bidirectional relationships between parents/peers and youth attitudes were not directly tested in this study, results suggest a nonlinear pattern of changes and encourage more longitudinal research on the development of prejudice in adolescence. 
Other social factors that have been shown to influence intergroup attitudes are class/school environment and teachers. Higher exposure to teaching about critical thinking as well as multiculturalism is related to lower levels of anti-immigrant attitudes in schools where they adopt a multicultural school curriculum in Sweden (Hjerm, Sevä, \& Werner, 2018). Further, students in schools with a high proportion of certified teachers were less likely to have anti-immigrant attitudes indicating that certified teachers might have a better understanding of the diversity emphasis in the curricula, societal norms, and the Education Act (i.e., system that contains basic principles and provisions for education and which aims to actively deal with racism and intolerance, whenever confronted with such sentiments in schools) (Hjerm, Sevä, \& Werner, 2018). In a similar line, across three studies, Geerlings, Thijs, and Verkuyten (2017) demonstrated that high-quality student-teacher relationships and teachers' desire for intercultural openness were associated with more positive attitudes towards immigrants. Similar to findings regarding parents' openness to a political discussion with their children, the students whose teachers discussed political issues were more likely to report higher levels of positive attitudes towards immigrants compared to students whose teachers did not discuss politics in the classroom (Bayram Özdemir, Stattin, \& Özdemir, 2016).

Overall, both developmental and social theories help us to understand and explore the developmentally relevant factors that researchers should focus on while designing approaches aimed at improving intergroup relations. Drawing upon these theories, empirical findings summarized above also indicate the importance of taking a comprehensive approach to interventions aimed at creating a more integrated society, as the development of intergroup attitudes is complex and multifaceted. Having reviewed the relevant literature on the social agents that influence prejudice and discrimination towards immigrants and refugees, which are also presented in detail in Table 1, we now turn to implications of psychological research on interventions which aim to promote intergroup relations.

\section{From Theory to Practice: Intervention Studies to Promote Intergroup Relations}

As research reveals multifaceted roots of the development of prejudice and discrimination, researchers avail themselves to design intervention strategies to reduce prejudice and discrimination and promote positive intergroup relations among children and adolescents. Interventions aiming to promote intergroup attitudes can be traced back to Allport's Intergroup Contact Theory, which argues that positive intergroup contact and reduction of prejudicial attitudes can be fostered in settings which meet a few basic criteria, including equal status between in-group and out-group members, common goals and cooperation, sanctioning of the intergroup contact by authority figures and meaningful interaction between in-group and out-group members (Allport, 1954).

Both cross-sectional studies and longitudinal studies revealed that adolescents who have many opportunities for contact, positive attitudes about contact, perceived positive social norms about out-groups, and high levels of behavioral control were more likely to develop intergroup friendship with immigrants (Pettigrew \& Tropp, 2006; Titzmann, Brenick \& Silbereisen, 2015). Further, recent research in Italy con- 
ducted by Vezzali et al. (2018) has shown that elementary school children (mean age $=9.55$ years) who have contact with immigrants held less prejudice toward a secondary out-group (people with disabilities) which indicates the secondary transfer of the contact effect to another out-group. This line of research indicates that crossgroup friendships, school diversity, and inclusive policies at school are significant predictors of children's and youth's intergroup attitudes.

Contrary to the findings suggesting improvement of intergroup relations with contact, there are also studies showing that contact does not always work. For example, in a sample of Dutch adolescents, Vervoort, Scholte, and Scheepers (2011) found that participants (aged 12-16 years) were more likely to have negative attitudes towards immigrants when they were exposed to a growing number of immigrant students. In a similar vein, a cross-national study across 25 countries showed that 14-year-old adolescents' support for immigrant rights was not related to school ethnic composition or contact (Barber, Torney-Purta, \& Fennelly, 2010). Considering these mixed findings regarding the contact hypothesis, there is a need for further understanding of how different factors work together and influence interethnic relationships. Furthermore, it is not always clear whether diverse contexts necessarily meet Allport's conditions for positive intergroup contact, and future interventions should aim to ensure that these criteria are met.

The extended contact hypothesis posits that merely knowing that an in-group member has a close relationship with one or more out-group members can reduce prejudice (Cameron, Rutland, Hossain, \& Petley, 2011). For example, Vezzali, Hewstone, Capozza, Trifiletti, \& Di Bernardo (2017) found that extended contact was related to improved intergroup empathy, which, in turn, was related to an increase in positive out-group attitudes and behavioral intentions in Italian elementary students aged between 8 and 11 years. Research testing different models of extended contact, including dual identity, common group identity, and de-categorization, demonstrates that dual identity interventions (i.e., inducing members of different groups to identify with an inclusive, superordinate identity group by recognizing subgroups' differences simultaneously) were the most effective in changing 5- to 11-year-old children's intergroup attitudes toward refugees (Cameron, Rutland, Brown \& Douch, 2006).

Additionally, vicarious contact through media has also been found effective in promoting positive intergroup relations. For instance, viewing a version of Sesame Street that was specially designed to present positive intergroup contact between Israelis and Palestinians was associated with more positive and prosocial reasoning when thinking about other's intentions. Findings also showed that children were more likely to respond with more inclusive explanations after the intervention (e.g., children from different cultural backgrounds could be friends) (Brenick et al., 2007). There are new opportunities to continue to examine the role that the media may play. For instance, the MacArthur Foundation recently funded the Sesame Workshop and the International Rescue Committee to develop an adapted version of Sesame Street that will be available to Syrian refugees and local children across Jordan, Lebanon, Iraq, and Syria. Their aims are to teach preschool-aged children language and social skills along with inclusive attitudes surrounding issues of race, and diversity and nonaggressive ways of resolving the conflict by providing educational messages from the children's perspective. Such large-scaled media interventions and investigating their effectiveness can provide promising progress in early childhood services and have 
important implications for social cohesion around the world (MacArthur Foundation, 2017).

Other theorists have called for the integration of social-cognitive developmental phenomena in prejudice reduction (Aboud, 2008; Rutland \& Killen, 2015). They focus on changing children's and adolescents' intergroup attitudes by facilitating social, cognitive, and moral skills including social categorization, perspective-taking, empathy, and moral reasoning, as these are involved in intergroup attitudes and can be used to promote positive intergroup relations (for a review, see Levy, Lytle, Shin, \& Hughes, 2016).

\section{Why Does Understanding Attitudes towards Immigrants and Refugees Matter?}

Although the extant literature is largely focused on majority group children and adolescents, evidence suggests that the attitudes and experiences of racial and ethnic minority children often differ from those of majority group children (Verkuyten \& Fleischmann, 2017). Research has constantly demonstrated how discrimination and prejudice towards immigrant and refugee children negatively impact psychological well-being (e.g., depression and lowered self-esteem) and developmental progress (e.g., around the formation of peer relationships and optimal academic performance) and interrupts acculturative tasks (e.g., forming peer relationships, sense of belonging) (Sirin et al., 2015; Verkuyten \& Fleischmann, 2017). These consequences are particularly negative when discrimination is pervasive and systematic. A recent integrative risk and resilience model (Suárez-Orozco, Motti-Stefanidi, Marks, \& Katsiaficas, 2018) proposes that discrimination and prejudice are barriers to the adaptation of immigrant-origin children and youth. This model also suggests that intersections of some characteristics (race-ethnicity, gender, religion, socioeconomic status, and legal status) can shape the experiences of immigrant-origin children and youth.

Several qualitative studies have also explored the perception and perspectives of immigrants and refugees. For example, Wernesjö (2015) examined the perspective of unaccompanied young refugees between 16 and 19 years of age in Sweden about belonging, friendship, and home. One of the common themes was how they have struggled to get to know and become friends with youth they categorize as Swedish. Further, some of the participants suggest that difficulties are based on how "immigrants" or "refugees" are depicted as different and problematic. Similarly, in a recent qualitative study, Demir and Ozgul (2019) explored what Syrian children and adolescents (8- to 15-year-olds) think about their life in Turkey and whether they face discrimination and ostracism at school and in the community. Syrian children and adolescents reported that they faced discriminatory acts such as humiliation and rejection by peers in various places including schools, hospitals, and parks. Research also showed that immigrant children's perceptions can be shaped by intergroup processes. More specifically, Malti, Killen, and Gasser (2012) showed that non-Swiss adolescents (who have newly immigrated to Switzerland) view exclusion on the basis of group membership to be more wrong than ethnic majority adolescents, and they tend to attribute more positive emotions to the excluder. Similarly, another study which examines ethnic in-group and out-group attitudes among both Dutch and Turkish children showed that, for both minority and majority group members, stronger eth- 
nic identification was related to a less negative evaluation of an in-group perpetrator (Verkuyten, 2003).

Even though the causes and the correlates of intergroup attitudes towards immigrants and refugees are the focus of this review, understanding the origins of these attitudes can shed light on work to mitigate the consequences of negative intergroup interactions for immigrants and refugees. Thus, understanding the correlates of these attitudes is one of the first steps to deal with the host of negative psychological, physical, and academic outcomes which immigrant-origin children and youth face by perceived discrimination.

\section{Limitations and Future Directions}

In this review, we call attention to the limitations of the extant intervention literature to have a better understanding of the components of effective interventions. First, although the intervention studies summarized above have examined multiple factors, there might be other moderators (e.g., the context as an indication of tense or harmonious intergroup relationships; immigrant status) that may influence the effectiveness of the intervention.

Future studies should also overcome the other limitations of the current research, such as the lack of follow-up measures, targeting only one aspect of negative attitude reduction strategies despite the multifaceted nature of attitudes towards outgroups, and a failure to examine the effects of societal factors. Accordingly, future research should focus on longitudinal examinations of the effectiveness of intervention programs in order to best understand the developmental trajectories of attitudes in children, and to attend to the social context. Moreover, since the development of attitudes is multifaceted and is influenced by several individual and social factors, combining elements from effective training strategies tapping these factors would be more promising. It is also critical to point out that the aim of this review paper is examining the development of attitudes towards immigrants, therefore, conclusions drawn from this literature should be generalized to other domains of intergroup bias with caution.

\section{Implications for Educational and Social Policies}

Considering the literature on children's and adolescents' attitudes toward immigrants and refugees, we can conclude that while the gap between theory and research has been narrowing, the gap between research and practice is still wide. In this section, we present implications for school-based interventions as children and adolescents spend a great amount of their time at school, and school environments often provide them with their first opportunities for direct intergroup contact. However, opportunities for contact with children from different groups in class settings do not guarantee positive intergroup experiences (Rivas-Drake, Saleem, Schaefer, Medina, \& Jagers, 2018). Thus, interventions should target fostering positive social climates of schools, where school principals, educators, and educational psychologists attend to the unique needs of immigrant and refugee children and support their well-being and positive intergroup interactions. 
In a recent review, Jones and Rutland (2018) examined studies which demonstrated how parents, peers, and teachers shape anti-immigrant attitudes among youth. They argued that school-based interventions aimed at promoting intergroup relations should consider the broader social context in which youth live by adopting a multicultural approach to diversity (i.e., celebrating both group differences and similarities between groups to promote quality contact by social integration) instead of a color-blind approach. For example, Pirchio, Passiatore, Carrus, and Taeschner (2017) conducted a school-based intervention aimed at promoting cross-group friendships among primary school children by using foreign language learning activities. Results demonstrated that children in the intervention condition showed a decrease in their negative attitudes towards immigrant schoolmates after the intervention program compared to children in the control condition.

Another recent meta-analytic review that investigates school-based intervention studies to improve out-group attitudes showed that antibias interventions in schools (classroom-wide programs and one-on-one interventions) generally promote positive attitudes toward out-group members (Ülger, Dette-Hagenmeyer, Reichle, \& Gaertner, 2018). This review suggests that the status of the participants, target outgroup of the intervention, level of exposure, intervention strategies or duration, influence variation in the effectiveness of the school-based intervention. One important conclusion from this meta-analysis is that researchers and school personnel need to develop interventions that consider the realities of the school environment by identifying efficient and practical strategies that can be applied to entire classrooms on a continuing basis. Another important, powerful practice is that researchers, teachers, and school principals should design interventions that can be effective across a broad range of intergroup contexts to encourage cultural pluralism considering the heightened need to create inclusive environments.

Despite these calls regarding the involvement of different dynamics in future intervention research, the issue of incorporation of intervention into routine educational practices remains still neglected. In particular, researchers and teachers should collaborate to design programs to integrate aims regarding promoting intergroup relations into their strategic plans to be able to monitor their effects on positive school climate and both minority and majority students' social-emotional and academic outcomes. Intervention programs need to be tested using empirical studies which support using random assignment, appropriate control, multimethod and multi-informant outcome measures (e.g., from student and teachers), and systematic observation of implementation to meet the highest methodological standards. The individual and contextual variables related to the effectiveness of the program should be identified to foster healthy developmental outcomes and to provide insight into why effects may not be identical across the schools and even classrooms. Further, intervention programs should allow the researcher to follow the maintenance of the program after the initial stage by being a part of the schools' continuous antibullying work rather than being an intervention study that lasts for a limited time. As motivation is one of the key components of intervention aiming to promote positive attitudes towards immigrants and refugees, researchers' support for the school is very critical. Thus, program developers and researchers should investigate the factors which interfere with the motivation of students, teachers, and school principals and provide more effective ways to sustain and increase their motivation for implementing the program.

Attitudes towards Immigrants and Refugees in Children and Adolescents
Human Development 2019;63:90-111 DOI: $10.1159 / 000503173$ 
Moving forward, other school-based programs focused on preventing learning, behavior, and social-emotional problems should establish better connections with antibias intervention programs for promoting positive intergroup relations. For example, there is great evidence that school-based social-emotional learning programs improve children's social and emotional skills and academic performance (Durlak, Weissberg, Dymnicki, Taylor, \& Schellinger, 2011). However, typically the activities in social-emotional learning programs neglect to consider intergroup relations to understand majority and minority children's and adolescents' social and emotional development in diverse contexts or multicultural classroom contexts that provide an opportunity for intergroup interaction. To be able to support the notion of school as one inclusive community, programs that attend to social-emotional learning should adopt an intergroup lens. One clear conclusion from this review is that we need new research that examines the nature of intergroup relations and intervention mechanisms at the levels of the individual, the family/peer ecology, and the broader systems in which children are nested.

Additionally, most of the interventions evaluated the majority children's attitudes toward immigrants and refugees. However, as the nature of intergroup relations is reciprocal, more research is necessary to examine immigrant and refugee children's attitudes towards majority youth to better understand how successful interventions are in promoting intergroup relations for both majority and minority group members. Thus, it is critical to examine immigrant and refugee children's and adolescents' perceptions of intergroup processes around themselves, and their perceptions about systems in the host society from micro to macro levels. Such research would help educational policies to achieve successful integration of immigrant and refugee children in the present educational system by informing them about the unique needs of these youth.

It is also worthwhile to consider the critical distinction between targeted outgroups while designing interventions to positively promote intergroup attitudes. As we discussed at the outset, immigrant status is one of the important factors shaping the majority individuals' intergroup attitudes toward the out-group. Specifically, adults demonstrate considerably higher prejudice towards illegal immigrants and refugees compared to legal immigrants (Lee \& Fiske, 2006). Yet, we know little about how or whether children and adolescents differentiate heterogeneity in the immigration status (Jones \& Rutland, 2018). Goldfarb, Lagattuta, Kramer, Kennedy, \& Tashjian (2017) examined children's perceptions of who is a noncitizen and their beliefs about the rationale for social group regulations. Their findings showed that children have growing developmental awareness that laws regulating social groups may arise from differences between the groups with age. In another study, Brown (2011) demonstrated that children hold higher negative attitudes toward illegal immigrants compared to legal immigrants and believed that they should go to jail. Thus, the effectiveness of interventions may depend on the characteristic of the out-group and keeping the differences between immigrant status in mind may make an important contribution to future research to foster more equitable developmental outcomes for all children and youth.

In sum, this review aims to spark systematic research that explores pathways from intergroup contact to positive intergroup attitudes among children and youth, and translate theoretical and contextual issues into applied settings to demonstrate implications of the development of positive intergroup relations for young people, their families, and their society. 


\section{Acknowledgments}

We are grateful to the youth, families, and educators who participated in the studies reported in this review. We also thank the authors of the studies reported in the current review paper.

\section{Statement of Ethics}

The authors have no ethical conflicts to disclose.

\section{Disclosure Statement}

The authors have no conflicts of interest to declare.

\section{Funding Sources}

The authors received no financial support for the research, authorship, and/or publication of this article.

\section{Author Contributions}

The first author made a substantial contribution to the conception or design of the work, the review of the relevant literature and manuscript preparation; The second author made substantial contributions to the conception or design of the work and revising it critically for important intellectual content.

\section{References}

Aboud, F. E. (2008). A social-cognitive developmental theory of prejudice. In S. M. Quintana \& C. McKown (Eds.), Handbook of race, racism, and the developing child (pp. 55-71). Hoboken, NJ: Wiley. https://doi.org/10.1002/9781118269930.ch4

Aboud, F. E., \& Sankar, J. (2007). Friendship and identity in a language-integrated school. International Journal of Behavioral Development, 31(5), 445-453. https://doi.org/10.1177/0165025407081469

Allport, G. W. (1954). The nature of prejudice. Cambridge, MA: Addison-Wesley.

Arlt, D., Dalmus, C., \& Metag, J. (2019). Direct and indirect effects of involvement on hostile media perceptions in the context of the refugee crisis in Germany and Switzerland. Mass Communication \& Society, 22(2), 171-195. https://doi.org/10.1080/15205436.2018.1536791

Barber, C., Torney-Purta, J. \& Fennelly, K. (2010, July). Adolescents' attitudes toward immigrants' rights and nationalism in 25 countries. Paper presented at the 4th International Association for the Evaluation of Educational Achievement (IEA) International Research Conference, Gothenburg. https://doi. org/10.1080/10888691.2013.774870

Bayram Özdemir, S., Stattin, H., \& Özdemir, M. (2016). Youth's initiations of civic and political discussions in class: Do youth's perceptions of teachers' behaviors matter and why? Journal of Youth and Adolescence, 45(11), 2233-2245. https://doi.org/10.1007/s10964-016-0525-Z

Beißert, H., Gönültaş, S., \& Mulvey, K. L. (2019). Social inclusion of refugee and native peers among adolescents: It is the language that matters! Journal of Research on Adolescence. https://doi.org/10.1111/ jora. 12518

Brenick, A., Lee-Kim, J., Killen, M., Fox, N. A., Leavitt, L. A., \& Raviv, A. (2007). Social judgments in Israeli and Arabic children: Findings from media-based intervention projects. In D. Lemish \& M. Gotz (Eds.), Children, media and war (pp. 287-308). Cresskill, NJ: Hampton Press.

Attitudes towards Immigrants and Refugees in Children and Adolescents
Human Development 2019;63:90-111 DOI: $10.1159 / 000503173$ 
Bronfenbrenner, U. (1979). The ecology of human development: Experiments by nature and design. Cambridge, MA: Harvard University Press.

Brown, C. S. (2011). Elementary school children's attitudes about immigrants, immigration, and being an American. Journal of Applied Developmental Psychology, 32(3), 109-117. https://doi.org/10.1016/ j.appdev.2011.01.001

Brown, C. S., Ali, H., Stone, E. A., \& Jewell, J. A. (2017). U.S. children's stereotypes and prejudicial attitudes toward Arab Muslims. Analyses of Social Issues and Public Policy (ASAP), 17(1), 60-83. https://doi. org/10.1111/asap.12129

Buchanan, Z. E., Abu-Rayya, H. M., Kashima, E., Paxton, S. J., \& Sam, D. L. (2018). Perceived discrimination, language proficiencies, and adaptation: Comparisons between refugee and non-refugee immigrant youth in Australia. International Journal of Intercultural Relations, 63, 105-112. https://doi. org/10.1016/j.ijintrel.2017.10.006

Cameron, L., Rutland, A., Brown, R., \& Douch, R. (2006). Changing children's intergroup attitudes toward refugees: Testing different models of extended contact. Child Development, 77(5), 1208-1219. https:// doi.org/10.1111/j.1467-8624.2006.00929.x

Cameron, L., Rutland, A., Hossain, R., \& Petley, R. (2011). When and why does extended contact work? The role of high quality direct contact and group norms in the development of positive ethnic intergroup attitudes amongst children. Group Processes \& Intergroup Relations, 14(2), 193-206. https://doi. org/10.1177/1368430210390535

Degner, J., \& Dalege, J. (2013). The apple does not fall far from the tree, or does it? A meta-analysis of parent-child similarity in intergroup attitudes. Psychological Bulletin, 139(6), 1270-1304. https://doi. org/10.1037/a0031436

Demir, S. B., \& Ozgul, V. (2019). Syrian refugee minors in Turkey. Why and how are they discriminated against and ostracized? Child Indicators Research, 1-23. Advance online publication. https://doi. org/10.1007/s12187-019-9622-3

De Tezanos-Pinto, P., Bratt, C., \& Brown, R. (2010). What will the others think? In-group norms as a mediator of the effects of intergroup contact. British Journal of Social Psychology, 49(Pt 3), 507-523. https://doi.org/10.1348/014466609X471020

Durlak, J. A., Weissberg, R. P., Dymnicki, A. B., Taylor, R. D., \& Schellinger, K. B. (2011). The impact of enhancing students' social and emotional learning: A meta-analysis of school-based universal interventions. Child Development, 82(1), 405-432. https://doi.org/10.1111/j.1467-8624.2010.01564.x

Eckstein, K., Šerek, J., \& Noack, P. (2018). And what about siblings? A longitudinal analysis of sibling effects on youth's intergroup attitudes. Journal of Youth and Adolescence, 47(2), 383-397. https://doi. $\operatorname{org} / 10.1007 / \mathrm{s} 1096$

Geerlings, J., Thijs, J., \& Verkuyten, M. (2017). Student-teacher relationships and ethnic outgroup attitudes among majority students. Journal of Applied Developmental Psychology, 52, 69-79. https://doi. org/10.1016/j.appdev.2017.07.002

Gniewosz, B., \& Noack, P. (2015). Parental influences on adolescents' negative attitudes toward immigrants. Journal of Youth and Adolescence, 44(9), 1787-1802. https://doi.org/10.1007/s10964-0150291-3

Goldfarb, D., Lagattuta, K. H., Kramer, H. J., Kennedy, K., \& Tashjian, S. M. (2017). When your kind cannot live here: How generic language and criminal sanctions shape social categorization. Psychological Science, 28(11), 1597-1609. https://doi.org/10.1177/0956797617714827

Gönültaş, S., Selçuk, B., Slaughter, V., Hunter, J. A., \& Ruffman, T. (2019). The capricious nature of theory of mind: Does mental state understanding depend on the characteristics of the target? Child Development, 1-19. Advance online publication. https://doi.org/10.1111/cdev.13223

Hitti, A., Elenbaas, L., Noh, J. Y., Rizzo, M. T., Cooley, S., \& Killen, M. (2019). Expectations for crossethnic inclusion by Asian American children and adolescents. Group Processes \& Intergroup Relations, 1-20. Advance online publication. https://doi.org/10.1177/1368430219851854

Hitti, A., \& Killen, M. (2015). Expectations about ethnic peer group inclusivity: The role of shared interests, group norms, and stereotypes. Child Development, 86(5), 1522-1537. https://doi.org/10.1111/ cdev.12393

Hjerm, M., Eger, M. A., \& Danell, R. (2018). Peer attitudes and the development of prejudice in adolescence. Socius. Sociological Research for a Dynamic World, 4, 1-11. https://doi.org/10.1177/ 2378023118763187

Hjerm, M., Sevä, I., \& Werner, L. (2018). How critical thinking, multicultural education and teacher qualification affect anti-immigrant attitudes. International Studies in Sociology of Education, 27(1), 42-59. https://doi.org/10.1080/09620214.2018.1425895 
Jones, S., \& Rutland, A. (2018). Attitudes toward immigrants among the youth: Contact interventions to reduce prejudice in the school context. European Psychologist, 23(1), 83-92. https://doi.org/ 10.1027/1016-9040/a000310

Killen, M., Rutland, A., Abrams, D., Mulvey, K. L., \& Hitti, A. (2013). Development of intra- and intergroup judgments in the context of moral and social-conventional norms. Child Development, 84(3), 1063-1080. https://doi.org/10.1111/cdev.12011

Lee, L. T., \& Fiske, S. (2006). Not an outgroup, not yet an ingroup: Immigrants in the stereotype content model. International Journal of Intercultural Relations, 30(6), 751-768. https://doi.org/10.1016/ j.ijintrel.2006.06.005

Levy, S. R., \& Killen, M. (Eds.) (2008). Intergroup attitudes and relations in childhood through adulthood. Oxford, UK: Oxford University Press.

Levy, S. R., Lytle, A., Shin, J. E., \& Hughes, J. M. (2016). Understanding and reducing racial and ethnic prejudice among children and adolescents. In D. Nelson (Ed.), Handbook of prejudice, stereotyping, and discrimination (pp. 455-484). New York, NY: Psychology Press.

MacArthur Foundation (2017). Sesame workshop \& international rescue committee awarded $\$ 100$ million for early childhood education of Syrian refugees. Retrieved from https://www.macfound. org/press/press-releases/sesame-workshop-and-international-rescue-committee-awarded100-million-early-childhood-education-syrian-refugees/

Malti, T., Killen, M., \& Gasser, L. (2012). Social judgments and emotion attributions about exclusion in Switzerland. Child Development, 83(2), 697-711. https://doi.org/10.1111/ j.1467-8624.2011.01705.x

Meeusen, C., \& Dhont, K. (2015). Parent-child similarity in common and specific components of prejudice: The role of ideological attitudes and political discussion. European Journal of Personality, 29(6), 585-598. https://doi.org/10.1002/per.2011

Miklikowska, M. (2016). Like parent, like child? Development of prejudice and tolerance towards immigrants. British Journal of Psychology, 107(1), 95-116. https://doi.org/10.1111/bjop.12124

Miklikowska, M. (2017). Development of anti-immigrant attitudes in adolescence: The role of parents, peers, intergroup friendships, and empathy. British Journal of Psychology, 108(3), 626-648. https:// doi.org/10.1111/bjop.12236

Miklikowska, M. (2018). Empathy trumps prejudice: The longitudinal relation between empathy and anti-immigrant attitudes in adolescence. Developmental Psychology, 54(4), 703-717. https://doi. org/10.1037/dev0000474

Miklikowska, M., Thijs, J., \& Hjerm, M. (2019). The impact of perceived teacher support on anti-immigrant attitudes from early to late adolescence. Journal of Youth and Adolescence, 48(6), 11751189. https://doi.org/10.1007/s10964-019-00990-8

Mulvey, K. L., Hitti, A., \& Killen, M. (2013). Intentionality, morality, and exclusion: How children navigate the social world. In M. Banaji \& S. Gelman (Eds.), Navigating the social world: What infants, children and other species can teach us (pp. 377-384). Oxford, UK: Oxford University Press. https://doi.org/10.1093/acprof:oso/9780199890712.003.0070

Munniksma, A., Flache, A., Verkuyten, M., \& Veenstra, R. (2012). Parental acceptance of children's intimate ethnic outgroup relations: The role of culture, status, and family reputation. International Journal of Intercultural Relations, 36(4), 575-585. https://doi.org/10.1016/j.ijintrel.2011.12.012

Nesdale, D. (2004). Social identity processes and children's ethnic prejudice. In M. Bennett \& F. Sani (Eds.), The development of the social self (pp. 219-246). Hove, UK: Psychology Press. https://doi. org/10.4324/9780203391099_chapter_8

Nesdale, D. (2008). Peer group rejection and children's intergroup prejudice. In S. R. Levy \& M. Killen (Eds.), Intergroup attitudes and relations in childhood through adulthood (pp. 32-46). Oxford, UK: Oxford University Press.

Nesdale, D. (2017). Children and social groups: A social identity approach. In A. Rutland, D. Nesdale, \& C. S. Brown (Eds.), The Wiley handbook of group processes in children and adolescents (pp. 3-23). Chichester, UK: John Wiley \& Sons. https://doi.org/10.1002/9781118773123.ch1

Nshom, E., \& Croucher, S. (2017). Perceived threat and prejudice towards immigrants in Finland: A study among early, middle, and late Finnish adolescents. Journal of International and Intercultural Communication, 11, 324-338. https://doi.org/10.1080/17513057.2017.1312489

Nucci, L. (1981). Conceptions of personal issues: A domain distinct from moral or societal concepts. Child Development, 52(1), 114-121. https://doi.org/10.2307/1129220

Nucci, L. P. (2001). Education in the moral domain. Cambridge, UK: Cambridge University Press. https://doi.org/10.1017/CBO9780511605987

Attitudes towards Immigrants and Refugees in

Children and Adolescents
Human Development 2019;63:90-111 DOI: $10.1159 / 000503173$ 
Pettigrew, T. F., \& Tropp, L. R. (2006). A meta-analytic test of intergroup contact theory. Journal of Personality and Social Psychology, 90(5), 751-783. https://doi.org/10.1037/0022-3514.90.5.751

Pirchio, S., Passiatore, Y., Carrus, G., \& Taeschner, T. (2017). Children's interethnic relationships in multiethnic primary school: Results of an inclusive language learning intervention on children with native and immigrant background in Italy. European Journal of Psychology of Education, 34(8), 1-14. https:// doi.org/10.1007/s10212-017-0363-8

Raabe, T., \& Beelmann, A. (2011). Development of ethnic, racial, and national prejudice in childhood and adolescence: A multinational meta-analysis of age differences. Child Development, 82(6), 1715-1737. https://doi.org/10.1111/j.1467-8624.2011.01668.x

Reches, L. H. L., \& Feddes, A. R. (2019). Similarity attracts: The role of personality in similarity perceptions and children's attitudes towards refugees. British Journal of Developmental Psychology. Advance online publication. https://doi.org/10.1111/bjdp.12285

Rivas-Drake, D., Saleem, M., Schaefer, D. R., Medina, M., \& Jagers, R. (2018). Intergroup contact attitudes across peer networks in school: Selection, influence, and implications for cross-group friendships. Child Development. Advance online publication. https://doi.org/10.1111/cdev.13061

Rutland, A., Cameron, L., Milne, A., \& McGeorge, P. (2005). Social norms and self-presentation: Children's implicit and explicit intergroup attitudes. Child Development, 76(2), 451-466. https://doi. org/10.1111/j.1467-8624.2005.00856.x

Rutland, A., \& Killen, M. (2015). A developmental science approach to reducing prejudice and social exclusion: Intergroup processes, social-cognitive development, and moral reasoning. Social Issues and Policy Review, 9(1), 121-154. https://doi.org/10.1111/sipr.12012

Rutland, A., Killen, M., \& Abrams, D. (2010). A new social-cognitive developmental perspective on prejudice: The interplay between morality and group identity. Perspectives on Psychological Science, 5(3), 279-291. https://doi.org/10.1177/1745691610369468

Schmuck, D., \& Matthes, J. (2015). How anti-immigrant right-wing populist advertisements affect young voters: Symbolic threats, economic threats and the moderating role of education. Journal of Ethnic and Migration Studies, 41(10), 1577-1599. https://doi.org/10.1080/1369183X.2014.981513

Sirin, S. R., Rogers-Sirin, L., Cressen, J., Gupta, T., Ahmed, S. F., \& Novoa, A. D. (2015). Discriminationrelated stress effects on the development of internalizing symptoms among Latino adolescents. Child Development, 86(3), 709-725. https://doi.org/10.1111/cdev.12343

Smith, S., Maas, I., \& van Tubergen, F. (2015). Parental influence on friendships between native and immigrant adolescents. Journal of Research on Adolescence, 25(3), 580-591. https://doi.org/10.1111/ jora. 12149

Stephan, W. G., Ybarra, O., \& Bachman, G. (1999). Prejudice toward immigrants. Journal of Applied Social Psychology, 29, 2221-2237. doi:10.1111-j.1559-1816.1999.tb00107.x

Suárez-Orozco, C., Motti-Stefanidi, F., Marks, A., \& Katsiaficas, D. (2018). An integrative risk and resilience model for understanding the adaptation of immigrant-origin children and youth. The American Psychologist, 73(6), 781-796. https://doi.org/10.1037/amp0000265

Titzmann, P. F., Brenick, A., \& Silbereisen, R. K. (2015). Friendships fighting prejudice: A longitudinal perspective on adolescents' cross-group friendships with immigrants. Journal of Youth and Adolescence, 44(6), 1318-1331. https://doi.org/10.1007/s10964-015-0256-6

Turiel, E. (1983). The development of social knowledge: Morality and convention. Cambridge, UK: Cambridge University Press.

Ülger, Z., Dette-Hagenmeyer, D. E., Reichle, B., \& Gaertner, S. L. (2018). Improving outgroup attitudes in schools: A meta-analytic review. Journal of School Psychology, 67, 88-103. https://doi.org/10.1016/ j.jsp.2017.10.002

United Nations (2016). International Migration Report - 2015 (ST/ESA/SER.A/384). New York, NY: Department of Economic and Social Affairs, Population Division.

van Zalk, M. H. W., \& Kerr, M. (2014). Developmental trajectories of prejudice and tolerance toward immigrants from early to late adolescence. Journal of Youth and Adolescence, 43(10), 1658-1671. https:// doi.org/10.1007/s10964-014-0164-1

Vaughn, B. E., \& Santos, A. J. (2009). Structural descriptions of social transactions among young children: Affiliation and dominance in preschool groups. In K. H. Rubin, W. Bukowski, \& B. Laursen (Eds.), Handbook of peer interactions, relationships, and groups (pp. 195-214). New York, NY: Guilford Press.

Vedder, P., Wenink, E., \& van Geel, M. (2017). Intergroup contact and prejudice between Dutch majority and Muslim minority youth in the Netherlands. Cultural Diversity \& Ethnic Minority Psychology, 23(4), 477-485. https://doi.org/10.1037/cdp0000150 
Verkuyten, M. (2003). Ethnic in-group bias among minority and majority early adolescents: The perception of negative peer behaviour. British Journal of Developmental Psychology, 21(4), 543-564. https:// doi.org/10.1348/026151003322535219

Verkuyten, M., \& Fleischmann, F. (2017). Ethnic identity among immigrant and minority youth. In A. Rutland, D. Nesdale, \& C. Spears Brown (Eds.), The Wiley handbook of group processes in children and adolescents. Chichester, UK: Wiley \& Sons. https://doi.org/10.1002/9781118773123.ch2

Verkuyten, M., \& Steenhuis, A. (2005). Preadolescents' understanding and reasoning about asylum seeker peers and friendships. Journal of Applied Developmental Psychology, 26(6), 660-679. https://doi. org/10.1016/j.appdev.2005.08.002

Vervoort, M. H., Scholte, R. H., \& Scheepers, P. L. (2011). Ethnic composition of school classes, majorityminority friendships, and adolescents' intergroup attitudes in the Netherlands. Journal of Adolescence, 34(2), 257-267. https://doi.org/10.1016/j.adolescence.2010.05.005

Vezzali, L., Di Bernardo, G. A., Stathi, S., Cadamuro, A., Lášticová, B., \& Andraščiková, S. (2018). Secondary transfer effect among children: The role of social dominance orientation and outgroup attitudes. British Journal of Social Psychology, 57(3), 547-566. https://doi.org/10.1111/bjso.12248

Vezzali, L., Hewstone, M., Capozza, D., Trifiletti, E., \& Di Bernardo, G. A. (2017). Improving intergroup relations with extended contact among young children: Mediation by intergroup empathy and moderation by direct intergroup contact. Journal of Community \& Applied Social Psychology, 27(1), 35-49. https://doi.org/10.1002/casp.2292

Wernesjö, U. (2015). Landing in a rural village: Home and belonging from the perspectives of unaccompanied young refugees. Identities (Yverdon), 22(4), 451-467. https://doi.org/10.1080/1070289X.2014. 962028

World Migration Report (2018). Retrieved from https://www.iom.int/wmr/world-migration-report-2018.

Attitudes towards Immigrants and Refugees in Children and Adolescents
Human Development 2019;63:90-111 DOI: $10.1159 / 000503173$ 